\title{
The Impact of the Massive Integration of Renewable Energies - Case of Morocco
}

\author{
Abdellah NAFIL ${ }^{1}$, Mostafa BOUZI ${ }^{2}$ \\ ${ }^{1}$ Ph.D., Student, Hassan I University - Settat- Morocco. \\ ${ }^{2}$ Higher education professor, Hassan I University - Settat- Morocco.
}

\begin{abstract}
Faced with a difficult energy context, marked by the foreseeable depletion of fossil fuels (coal, oil, natural gas) and their harmful effects on the environment, it is becoming urgent to deploy all our efforts to seek new, clean and inexhaustible sources of energy. On the other hand, the integration of renewable energy production into electrical systems is a new issue for network managers, due in particular to the variable and random nature of the primary sources involved. Our objective is to provide governments that intend to invest heavily in green energy with a global view of the essential elements to be taken into consideration for successful integration in the best conditions of security, stability and cost. To do so, we deal in this study with the case of Morocco.
\end{abstract}

Keywords: Steady state analysis; transient stability; renewable energy; Transmission network; PSS-E.

\section{INTRODUCTION}

Today, energy consumption accounts for $80 \%$ of $\mathrm{CO} 2$ emissions, which is the main source of global warming and causes the most dangerous effects of climate change. Thus, it is indisputable that all efforts to effectively reduce $\mathrm{CO} 2$ emissions and mitigate climate change must include the energy sector [1].

Concerns about the depletion of fossil energy sources, energy security issues and growing environmental problems have led policymakers to pay greater attention to renewable energy sources worldwide [2].

The main advantage of renewable energies is that they are free of direct pollution and carbon emissions. Given the concern about global warming caused by carbon emissions, significant efforts have been made to increase renewable energy penetration [3].
The Kingdom of Morocco is a country in the Maghreb Region of North Africa [4]. Its eastern border is with Algeria and a relatively narrow stretch of water on the northern side separates it from Spain. Predictions of climate change and global warming studies have shown that Morocco is among the most developed countries likely to be threatened by climate change [5].

Meeting energy needs in the most appropriate form is the great challenge of the world in the 21st century. The Moroccan authorities are fully aware of this challenge, particularly in view of the demographic and economic growth that is leading to a sharp increase in energy demand [6].

In view of these facts, the Ministry of Energy in partnership with the National Office of Electricity and Drinking Water (ONEE) has put in place a national energy strategy favorable to the development of this type of energy. This strategy is mainly based on the following points:

- $\quad$ Strengthen the security of energy supply by diversifying sources and resources.

- Optimize the energy balance: build 2000 MW of solar capacity and $2000 \mathrm{MW}$ of wind capacity by 2020 .

- $\quad$ Provide access to energy to the population at an affordable and competitive price.

- Achieving sustainable development objectives through the promotion of renewable energies.

- Promote productivity and competitiveness.

- Protect the environment and reduce greenhouse gas emissions.

- Strengthening regional integration by opening up EuroMediterranean energy markets and harmonizing energy legislation [7].

\begin{tabular}{|c|c|c|}
\hline Capacité & $\begin{array}{l}\text { (1) PROGRAMME ENERGIE SOLAIRE } \\
>2000 \mathrm{MW}\end{array}$ & $\begin{array}{l}2 \text { PROGRAMME ENERGIE EOUENNE } \\
>2000 \mathrm{MW} \text { (dont } 1000 \mathrm{MW} \text { dejà en fonction ou en } \\
\text { développement) }\end{array}$ \\
\hline Production annuelle & $>4500 \mathrm{GWh}$ & $>6600 \mathrm{GWh}$ \\
\hline Investissement & $>9$ miliards de USD & $>3.5$ milliards de USD \\
\hline Sites & $\begin{array}{l}\text { > } 5 \text { stes identifiés (Ain Beni Mathar, Ouarzazate, } \\
\text { Sebikhate Tah, Foum Al Ouad, Boujdour, }-10000 \text { ha) }\end{array}$ & $\begin{array}{l}\text { > } 5 \text { nouveaux stes (Taza, Koudia Al Baida, Seudouk, } \\
\text { Tiskrad, Boujbour) }\end{array}$ \\
\hline Calendrier & $\begin{array}{l}\text { > 1ère centrale solare: } 2015 \\
\text { > Finalisation du programme : } 2019\end{array}$ & $\begin{array}{l}\text { > 1ère centrale solaire: } 2014 \\
\text { > Finalisation du programme : } 2020\end{array}$ \\
\hline Economie & $\begin{array}{l}>1 \text { milion de teplan } \\
>3,7 \text { millions démission de tonnes COZjan }\end{array}$ & $\begin{array}{l}>1,5 \text { million de tep/an } \\
>5,6 \text { millions démission de tonnes } \mathrm{CO} 2 \text { an }\end{array}$ \\
\hline
\end{tabular}

Fig1. Moroccan Renewable Energies Program by 2020[8] 


\section{RELATED WORK}

Nowadays, several countries have understood the benefits of wind energy and are dedicated to its exploitation, however, a large part of the researchers have been digging into the problem of the integration of renewable energy plants, its research is focused on different aspects, namely :

\section{Impact on Production Forecasts}

According to Holttinen [9], the major problem with wind power is the uncertainty of wind speed, which leads to uncertainty in production. Indeed, wind energy forecasting plays an important role in the integration into the supply-demand balance on a large scale: it is put to the test during periods of high wind energy production and over a horizon of up to 6 hours in advance, which gives time to react to variations in wind production. An estimate of the uncertainty, particularly the worst-case error, is important.

\section{Impact on the Network's Host Capacity:}

For - Georgilakis[10], wind turbines are, of course, mainly installed in well-ventilated locations. This can lead to wind production in regions with low local consumption (sites far from consumption areas) where the surplus has to be exported. A robust transmission system designed for wind power transmission is therefore necessary. Thus, the size of the power system, the distribution of generation capacity, and load variations play an important role in how intermittent generation is assimilated into the grid. If wind generation is well dispersed over a large area and correlated with load, then it is easier to integrate it into the grid.

A prospective study carried out in the area managed by the German operator EON NETZ plans the development of 1,000 $\mathrm{km}$ of additional lines for a wind capacity of 16,000 MW, a significant part of which will be offshore, for an amount of 550 million Euros [11]. However, it should be noted that the time required to reinforce a substation in France can take up to 5 years and the time required to build a new line can take up to 10 years and be subject to significant opposition from the population. RTE has evaluated the capacity of the French network, without major adaptation, between 6,000 and 7,000 MW of wind power [12].

\section{Unintentional disconnection:}

Normal operation of the power system is a power transfer state in which the system can withstand a design fault without the resulting disturbance extending beyond the permissible range. In an area of normal operation with normal power transfer states, faulty equipment can be disconnected in the event of a problem. Disturbances are not allowed to extend to a larger area or cause system failure.

In this context, wind turbines, like most decentralized generators, are very sensitive to grid disturbances and tend to disconnect quickly during a voltage dip (as soon as the voltage value is less than $80 \%$ of the nominal voltage) or a change in frequency. During the Italian blackout of 28 September 2003,
$3400 \mathrm{MW}$ of distributed generation disconnected when the grid frequency reached $49 \mathrm{~Hz}$ [13]. The operator EON Netz foresees that the risk of disconnection of $3000 \mathrm{MW}$ of wind power due to a major fault in the $380 \mathrm{kV}$ grid in northern Germany is very real [10], which could lead to an imbalance between production and consumption, aggravating the consequences of a fault that could have been eliminated normally.

\section{METHOD}

The integration of renewable energy production into power systems is a new issue for grid operators, due in particular to the variable - or even random - nature of the primary sources involved. Like any means of production, renewable energy production units must, in order to be connected to the grid, comply with a certain number of technical constraints linked to the operation of electrical systems. Some of these constraints will be redefined taking into account the specificities of renewable energy production. The variability primary energy sources of renewable origins has made it necessary to carry out studies in order to analyze the global impact of this energy on an electrical system and to estimate its integration into the system.

Generally speaking, our objective is to provide governments that intend to invest heavily in green energy with a comprehensive idea of the essential elements that must be taken care of in order to achieve integration under the best conditions of security, stability and cost. And in a particular way, take the example of the Moroccan context with its ambitious green energy projects in order to analyze the operating constraints on the MV/HV network likely to affect the management of the security, stability and safety of the network; in other words, to prevent all kinds of damage, and thus provide for the reinforcement of lines, the construction of new transformer stations, and the installation of means of compensation for reactive energy.

To do so, we start by modeling all the power generation plants as well as 400, 225 and $60 \mathrm{kv}$ lines in the PSS-E software before integrating the new renewable energy power plants. Then we proceed with the simulations that will be spread over two scenarios with the objective of doing the load balancing calculation and Load Flow (power transit, load flow or load balancing calculation) and to conclude an analysis of the results and recommendations will be presented.

\section{DATASET}

For the simulations, we will use Siemens' Power System Simulator for Engineering (PSS/E), which is a software tool used by power system engineers to simulate electrical power transmission networks in steady state and on time scales ranging from seconds to tens of seconds. It also allows for load flow or load distribution calculations (power transit, load flow or load distribution calculations).

In our study, the database will be composed of the country's energy consumption power plants including those based on 
renewable energy, transformers and HV/HVB lines.

\section{Moroccan Electricity Network}

The Moroccan electricity network is managed by a single public entity, the ONEE, which is in charge of electricity production, transmission and distribution. [4] ONEE is placed under the administrative and technical supervision of the Ministry of Energy, Mines, Water and Environment, under the Department of Energy and Mines [14].

They are banking on a strategy of diversification of energy production sources, thanks in particular to the country's various natural resources. Its installed capacity has increased by 558.5 MW, up $6.8 \%$ compared to that of 2016 , of which $33.6 \%$ is from renewable sources. [15].

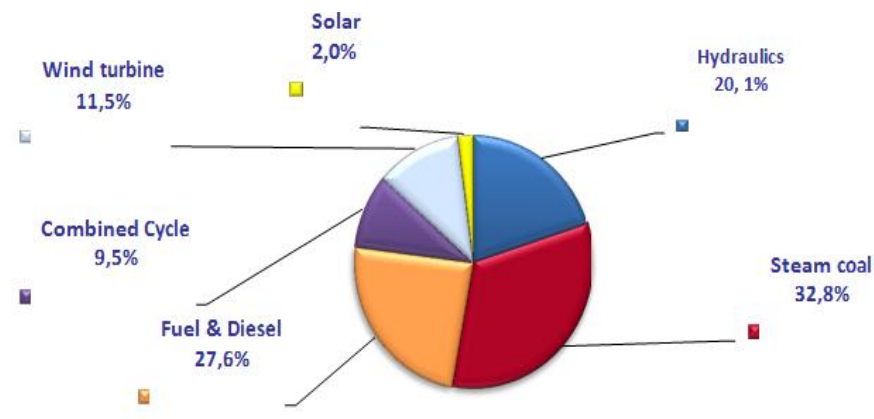

Fig2. Distribution of Power in Morocco according to Energy Sectors [15].

The ONEE has a transmission network linking the whole country, with a total length of $25,885 \mathrm{~km}$ in 2017 ; the function of this network is to transport electricity from generation plants to distribution stations, ensuring a balance between supply and demand. This balance guarantees supply under optimum conditions of safety, reliability and competitiveness.

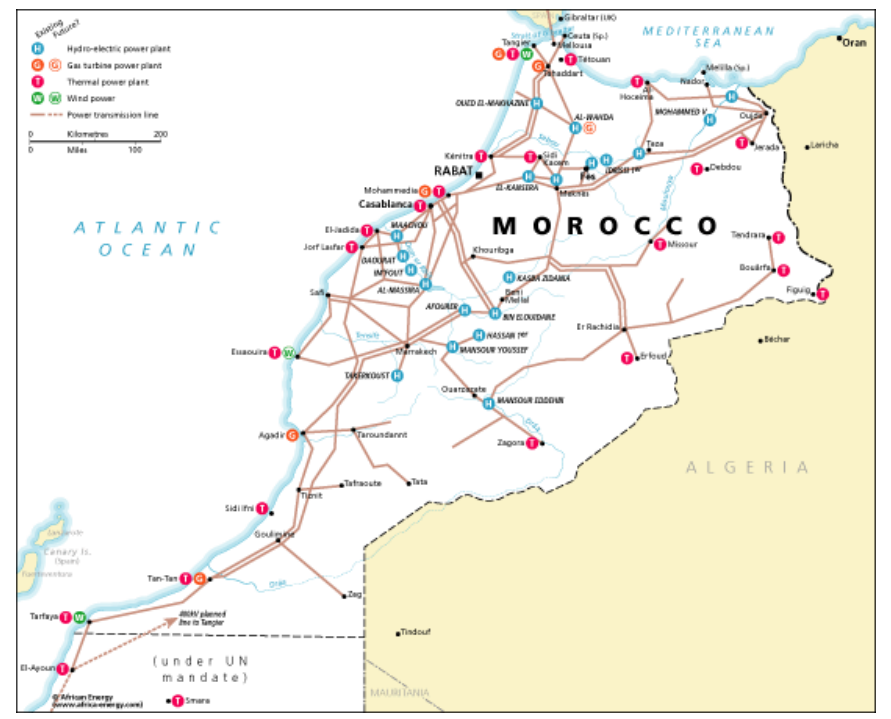

Fig3: Mapping of the Country's Energy Infrastructure in 2014 [16]
The transmission network covers the entire country and is connected to the Algerian and Spanish electricity grids via regional links. A connection to Mauritania is also under study.

The capacity of the link between Morocco and Spain is 1,400 MW via two $400 \mathrm{kV}$ Submarine cables. A third interconnection is also in progress. The connection with Algeria is a $1,500 \mathrm{MW}$ connection via one $400 \mathrm{kV}$ line and two $225 \mathrm{kV}$ lines. [15]

The main function of power grid systems is designed to support large generating plants serving distant consumers via two main connected systems: transmission and distribution.

Table 1. Power Installed in 2017 (in MVA) [15].

\begin{tabular}{|lcc|}
\hline & $\begin{array}{c}\text { Number } \\
\text { of Transfos }\end{array}$ & $\begin{array}{c}\text { Installed power } \\
\text { (MVA) }\end{array}$ \\
\hline VHV/HV & 154 & 20950 \\
\hline VHV/MV & 6 & 420 \\
\hline HT/MT & 377 & 7660 \\
\hline Total & $\mathbf{5 3 7}$ & $\mathbf{2 9 0 3 0}$ \\
\hline
\end{tabular}

Table 2. Length of Lines in 2017 (in km) [15].

\begin{tabular}{|lc|}
\hline & Length in $\mathbf{K m}$ \\
\hline Transport network & $25,885 \mathrm{~km}$ EHV/UV lines \\
\hline Distribution network & $220,500 \mathrm{~km}$ of LV lines \\
\hline
\end{tabular}

\section{National Renewable Energy Projects scheduled between 2020 and 2030}

The national energy plan is a roadmap that responds to Morocco's short, medium and long-term objectives for the development of the energy sector. It focuses on renewable energy and energy efficiency as key factors in achieving the country's commitment to reduce greenhouse gas emissions. In his statement at COP21 in Paris, His Majesty the King of Morocco confirmed Morocco's commitment to produce $42 \%$ by 2020 and $52 \%$ by 2030 of the energy required from renewable energies. Figure 3 illustrates the share of energy required to reach the 52\% target [17].

In 2015, Morocco's power generation capacity was 8,154 MW, distributed as follows: coal (31\%), fuel oil and diesel (10\%), hydroelectric power $(22 \%)$, gas $(25.8 \%)$ and wind $(9.4 \%)$. Solar and wind energy will account for more than 4,000 MW of this vision. [18] 


\section{Renewables share benchmark 2015-2030}

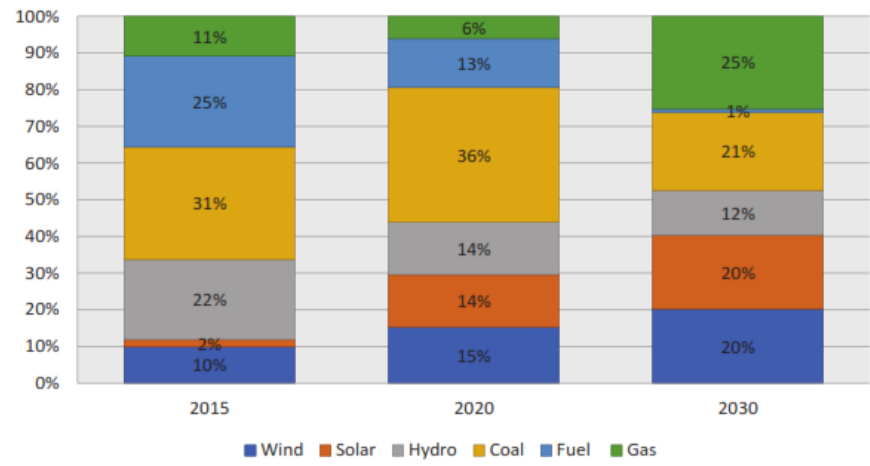

Fig4: Morocco's Renewable Energies Share Benchmark 2015-2030[18]

By 2030, Morocco is implementing new legislation and creating project development institutions to enable the implementation of international projects. Indeed, the projects planned between 2016 and 2030 represent 4,560 MW of solar energy, 4,200 MW of wind power and 1,330 MW of hydroelectric projects. Figure 7 shows the main projects that are currently under construction. Thus, the country aims to reduce its energy dependency on non-renewable sources to less than $82 \%$ by 2030 .

Table 3. Installed Power of Main RE Projects [15].

\begin{tabular}{|c|c|c|c|}
\hline Energy & $\begin{array}{c}\text { Name of the } \\
\text { project }\end{array}$ & $\begin{array}{c}\text { Installed } \\
\text { power }\end{array}$ & Framework \\
\hline \multirow{6}{*}{ Wind turbine } & Tangier II & $100 \mathrm{MW}$ & $\begin{array}{c}1000 \mathrm{Mw} \text { Integrated } \\
\text { Wind } \\
\text { Energy Program }\end{array}$ \\
\hline & Boujdour & $100 \mathrm{MW}$ & $\begin{array}{c}1000 \text { Mw Integrated } \\
\text { Wind } \\
\text { Energy Program }\end{array}$ \\
\hline & Tiskrad & $300 \mathrm{MW}$ & $\begin{array}{c}1000 \mathrm{Mw} \text { Integrated } \\
\text { Wind } \\
\text { Energy Program }\end{array}$ \\
\hline & Midelt & $150 \mathrm{MW}$ & $\begin{array}{c}1000 \text { Mw Integrated } \\
\text { Wind } \\
\text { Energy Program }\end{array}$ \\
\hline & JbelLahdid & $200 \mathrm{MW}$ & $\begin{array}{c}1000 \mathrm{Mw} \text { Integrated } \\
\text { Wind } \\
\text { Energy Program }\end{array}$ \\
\hline & Taza & 150 & $\begin{array}{c}1000 \mathrm{Mw} \text { Integrated } \\
\text { Wind } \\
\text { Energy Program }\end{array}$ \\
\hline Hydroelectric & $\begin{array}{c}\text { STEP } \\
\text { Abdelmoumen }\end{array}$ & $350 \mathrm{MW}$ & Project ONEE \\
\hline \multirow[b]{3}{*}{ Solar } & $\begin{array}{l}\text { Project NOOR- } \\
\text { TAFILALT }\end{array}$ & $75-100$ & $\begin{array}{c}400 \mathrm{MW} \\
\text { PHOTOVOLTAIC } \\
\text { SOLAR PROGRAM }\end{array}$ \\
\hline & $\begin{array}{l}\text { Project NOOR- } \\
\text { ATLAS }\end{array}$ & 200 & $\begin{array}{c}400 \mathrm{MW} \\
\text { PHOTOVOLTAIC } \\
\text { SOLAR PROGRAM }\end{array}$ \\
\hline & $\begin{array}{l}\text { Project NOOR- } \\
\text { ARGANA }\end{array}$ & $100-125$ & $\begin{array}{c}400 \mathrm{MW} \\
\text { PHOTOVOLTAIC } \\
\text { SOLAR PROGRAM }\end{array}$ \\
\hline
\end{tabular}

\section{Energy Consumption in Morocco}

Morocco's energy profile is dominated by imported fossil fuels. Morocco imports about $69.9 \%$ of its energy supplies. Total primary energy consumption has increased by about $5 \%$ per year since 2002 and reached 18.8 MTOE (million T onnes of oil equivalent) in 2014, according to the OECD / IEA.

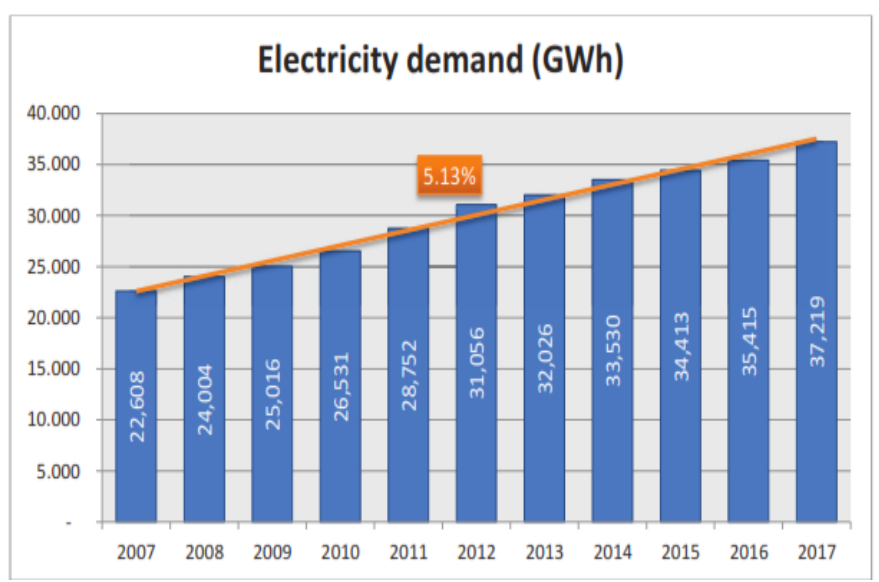

Fig5: History of Consumption 2007-2017 [19]

As a result of demographic and economic growth, the demand for electricity increased at an average annual rate of $5.13 \%$ between 2007 and 2017. The annual electricity demand recorded in 2017 is $37,219 \mathrm{GWh}$ and annual per capita consumption has been steadily increasing. To meet this demand, Morocco produced around 30,000 GWh and imported the rest of Spain and Algeria via various interconnections (Figure 1 below shows the sustained growth in demand between 2007 and 2017).

From a forecasting point of view (medium and long term), energy demand has become one of the most important tools for the management of international energy systems. After the first energy crisis, various energy demand studies focused on energy demand forecasting methods using various estimation models. Most of these models relate energy demand to social and economic parameters such as demographics, gross domestic product (GDP), and net income and energy prices.

Several publications have been shared in recent years dealing with energy consumption in Morocco; one of the first examples is by Noreddine CITROEN for "Le Développement des Prévisions d'Électricité à Long Terme pour le Maroc", which uses the non-linear autoregressive model (NLARX) based on a special class of artificial neural networks (ANN), namely Wavelet networks [20].

This modeling assumes that demand in Morocco will continue to grow at an average rate of $4.9 \%$ (against $6.4 \%$ for official forecasts) to reach $58 \mathrm{TWH}$ in 2025. 


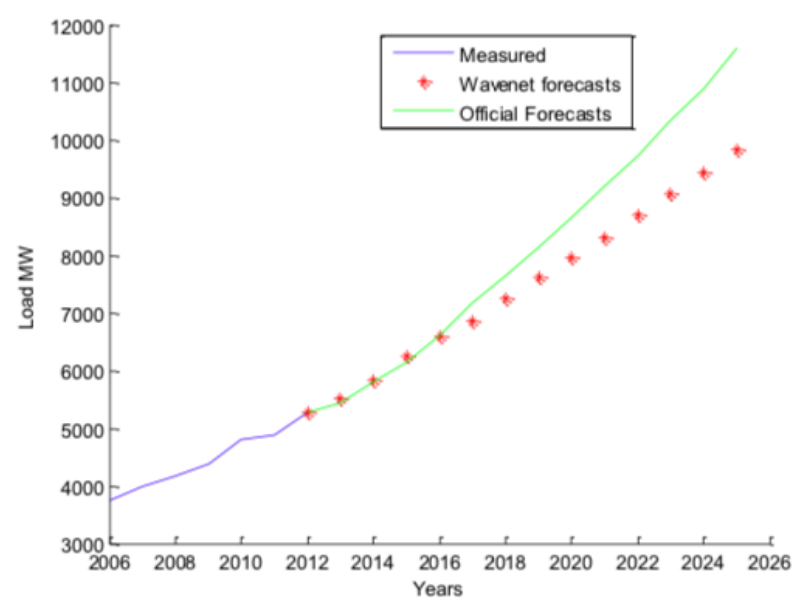

Fig6: Comparison of Official Forecasts and NLARX Model [5]

Another vision was proposed by Amin BENNOUNA. He established two models and compared the results: a first model based on energy intensity (EI) and another on the link with the country's urbanization rate (URB).EI is a measure of the energy efficiency of an economy that has segmented energy consumption into four components. The URB model, on the other hand, has only two components.

For the analysis of sensitivity to economic growth, BENNOUNA proposed three scenarios for the evolution of future GDP. In terms of results, the country's energy forecast should remain between $4.9 \%$ and $7.1 \%$ [21].

To meet this consumption requirement, our study will focus on the value of the maximum and minimum power (respectively during the evening peak and the night trough). According to the data published in the ONEE-BE annual activity report [19], a record peak was recorded in July 2018 at $6,172 \mathrm{MW}$ in addition to a trough of 3,516 MW. In 2020, and according to an optimistic scenario forecasting a $7.1 \%$ increase [20], the evening peak is estimated at $6,610 \mathrm{MW}$ and the night trough at 3,765 MW.

\section{Simulation approaches}

This study essentially identifies the state of the Moroccan transport network as an energy structure that should face the challenges described in the modeling and forecasts made for the year 2020. It is also based on the current database of the transmission network and will take into consideration all the elements constituting this infrastructure: the already existing power plants and those whose commissioning is planned, the HV substations, the HV lines (400, 225 and 60KV), but also the consumption forecasts for 2020.

The formulation of the problem of our study is therefore a simulation of two scenarios:

- P_max/Con_Max: This scenario is the image of maximum renewable energy production with maximum consumption (evening peak). It results in an energy evacuation from renewable energy plants located in places where consumption is very low.

- P_min / Con_Min: This scenario reflects minimal renewable energy production with minimal consumption.

\section{RESULT AND DISCUSSION}

The study that will be made is that of the Moroccan transport network, it will include the network planned for 2020 and is based on the database of the transmission network (Figure7). It will consist of (current and planned power stations), HV substations and line $(400,225$ and $60 \mathrm{KV})$, in addition to the consumption expected in 2020.

The study will be carried out using the PSS/E "Power System Simulation for Engineering" software, which allows the simulation of electrical power transmission networks under steady-state conditions and on time scales from a few seconds to several tens of seconds.

Through two scenarios, the results of the study will make it possible to:

- Establish the calculation of the Load Flow,

- Analyze voltage overruns and under runs on the power grid (Out of Limits Base Voltage)

- Analyze line and transformer overload (Limit Checking Branches)

- Establish the Optimal Power Flow calculation to assess the impact of the integration of the Strategic Energy Plan on the stability of the national power system.

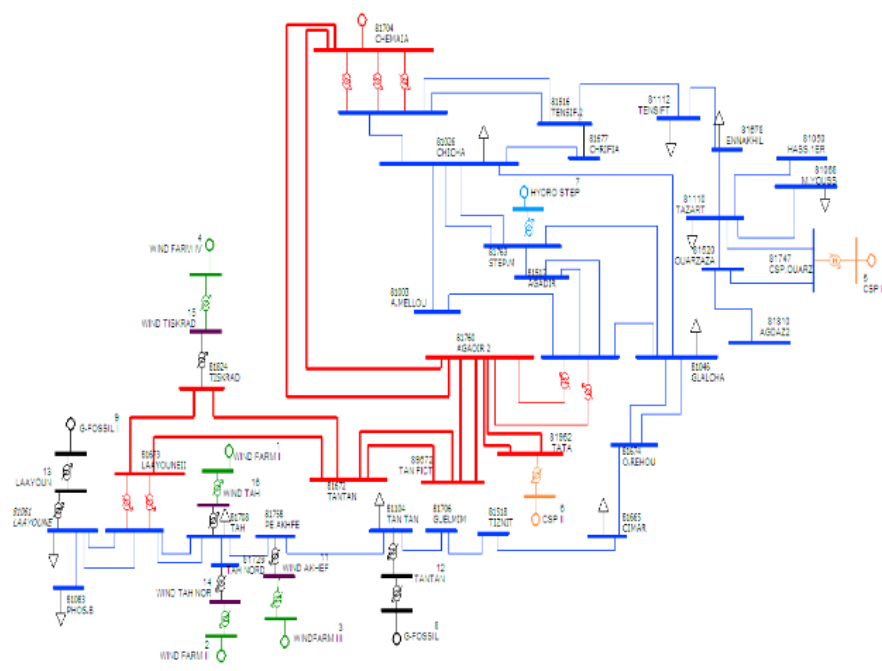

Fig7: The 2020 studied southern Moroccan transmission subnetwork.

\section{Assumptions}

The data that we will analyze are those of the estimated peak consumption in 2020, assuming that the renewable energy production park produces a maximum power that equals the installed power simultaneously with the maximum demand of the Moroccan electrical system. 
International Journal of Engineering Research and Technology. ISSN 0974-3154, Volume 13, Number 8 (2020), pp. 2081-2089

(C) International Research Publication House. https://dx.doi.org/10.37624/IJERT/13.8.2020.2081-2089

These two scenarios make it possible to verify the ability of the network to transport the

Energy produced and irrigates the consumption centers in full operation. The electrical examination of the state of operation of the network in this situation detects possible overloads and voltage anomalies at the connection points of the renewable energy production units. Our analysis will be divided into two simulations with the following assumptions:

- All wind generation (existing or planned connections) is modeled by the maximum active power they are capable of producing during the peak period.

- Taking into account the day/night cycle of photovoltaic production and the peak consumption time of $7 \mathrm{pm}$ leads to assume low photovoltaic production.

- Interconnection exchanges with Spain and Algeria are assumed to be zero.

- Overloads within acceptable limits (120\%) should not exceed 20 minutes.

\section{Scenarios}

A. Scenario I: Maximum production of ENRS (i.e. 100\% of the installed capacity) during the evening peak

This scenario is the image of maximum renewable energy production with maximum consumption (evening peak), it results in the evacuation of energy from renewable energy plants located in areas where consumption is very low.

\section{i. Power flow}

When the power produced by RE reaches $100 \%$ of its installed capacity, the wind production is at its maximum in a moment of the evening peak, the system converges without any problem; compared to the energy exchanges with neighboring countries, the energy balance Morocco-Spain is positive $+575.7 \mathrm{MW}$ which reflects an independence and internal energy satisfaction or even a strong possibility of selling energy via the Spanish European free market or/and the Algerian energy market.

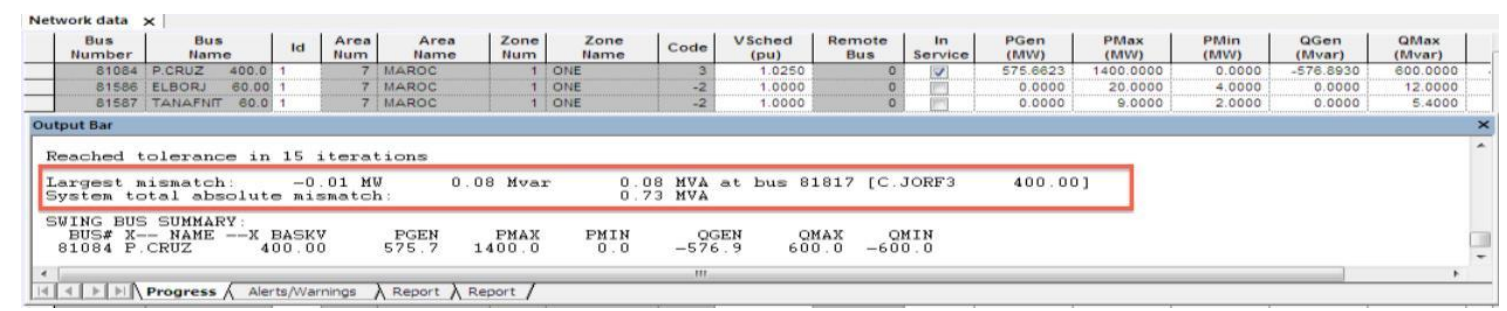

Fig8: Convergence of Scenario Pmax/PS

\section{ii. Line overloads}

With respect to line overloads, we note overruns on the $225 \mathrm{kV}$ lines of the transmission system. These include a $235.5 \%$ overload on the line between Laayoune and Phos Boucraa and a $253.5 \%$ overload on the $60 \mathrm{kV}$ line between Foum El Oued and Phos Boucraa.

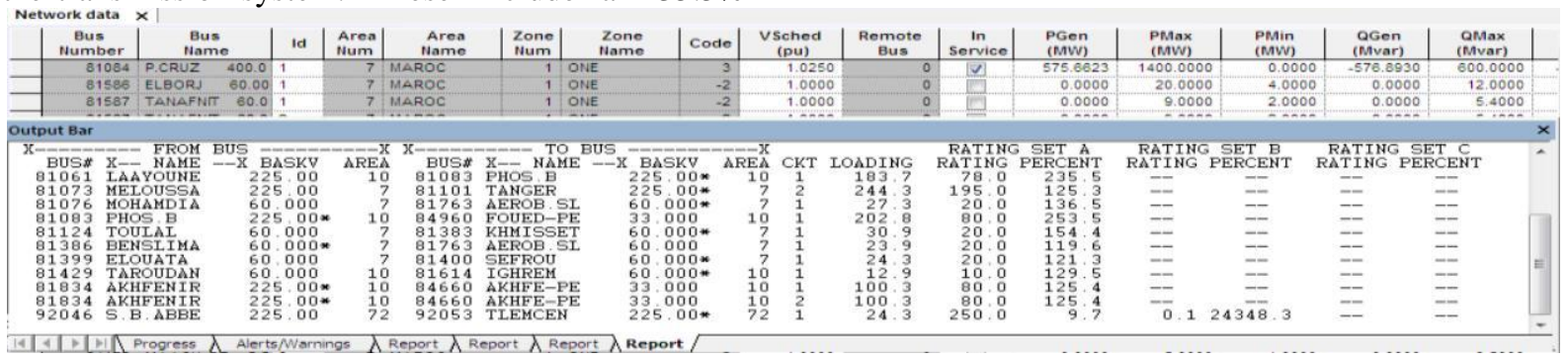

Fig9: Overloading of MV/HV lines

iii. Exceeding voltage limits

Concerning voltage limit exceedances, voltage crushing stresses occur in the network. These include voltage surges on $60 \mathrm{kV}$ buses, two of which are located in the southern region: Tantan $(53,842 \mathrm{kV})$ and Guelmime $(51,402 \mathrm{kV})$.

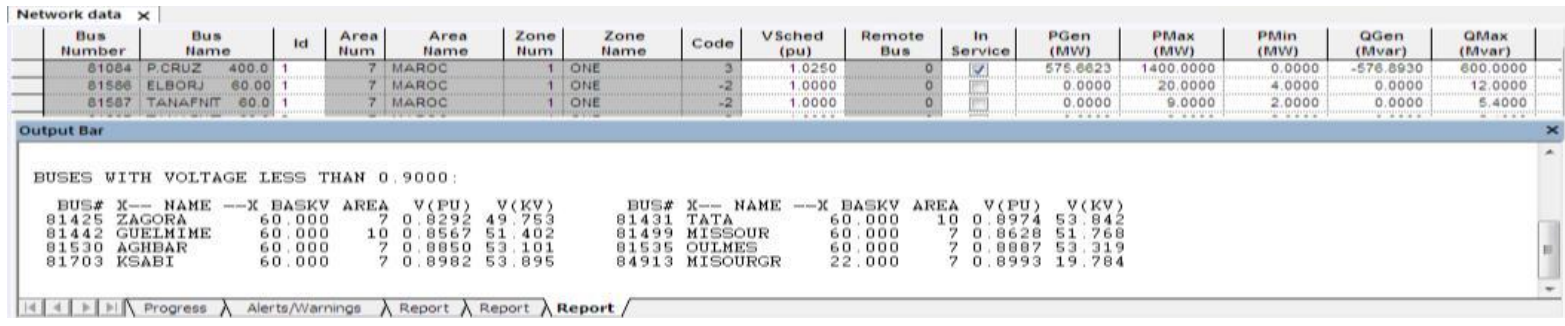

Fig 10: Exceeding voltage limits 
International Journal of Engineering Research and Technology. ISSN 0974-3154, Volume 13, Number 8 (2020), pp. 2081-2089

(C) International Research Publication House. https://dx.doi.org/10.37624/IJERT/13.8.2020.2081-2089

\section{B. Scenario II: Minimum ENRS production (i.e. $10 \%$ of installed capacity) during the evening peak}

In this scenario, we adjust the generation plan to have the generation from the renewable power plants correspond to $10 \%$ of the installed capacity, the simulation will be done at full load peak, we check for grid convergence, line overloads and voltage overruns.

\section{i. Power flow}

At the time of the simulation, we notice that the power system converges without any constraint; on the other hand the energy exchange becomes negative with a negative value of -115.11 MW, which imposes to the Moroccan power system operators an immediate action in order to respect the programmed exchange via the interconnections.

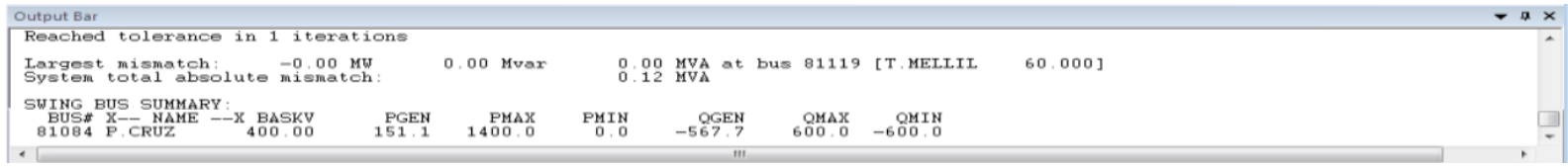

Fig11: Convergence of the Pmin/P.S. Scenario

\section{ii. Line overloads}

Overload constraints also appear in the national grid lines. An overload of $131.6 \%$ was recorded in the $225 \mathrm{kV}$ line connecting Meloussa to Tangier, and an overload of $128 \%$ between the 60 $\mathrm{kV}$ line connecting Taroudant to Ighrem: The overload Taroudant - Ighrem being part of the Southern network is considered acceptable, and does not cause a constraint to the network contrary to the recorded overload connecting the 225 $\mathrm{kV}$ busbar Meloussa (81073) Tangier (81101) which is significant.

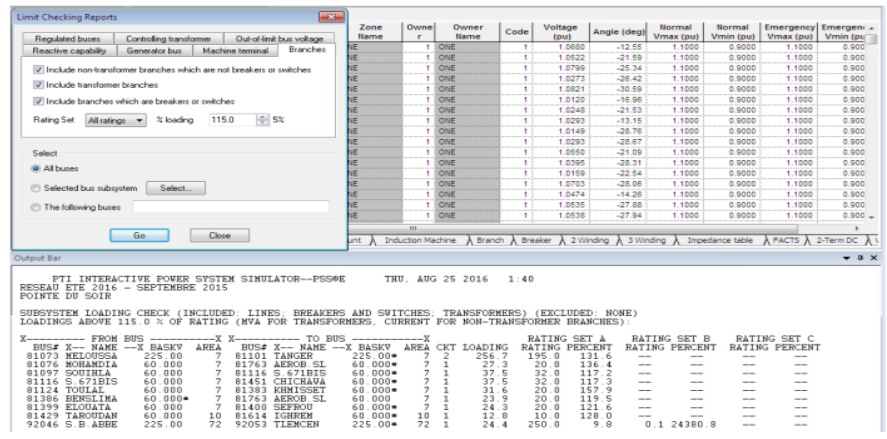

Fig12: Overloading of MV/HV lines

\section{iii. Exceeding voltage limits}

However, voltage crushing stresses are occurring in the national grid. These are especially crushing stresses on $60 \mathrm{kV}$ buses, but in the $400 \mathrm{kV}$ and $225 \mathrm{kV}$ network we do not detect any exceeding of voltage limits.

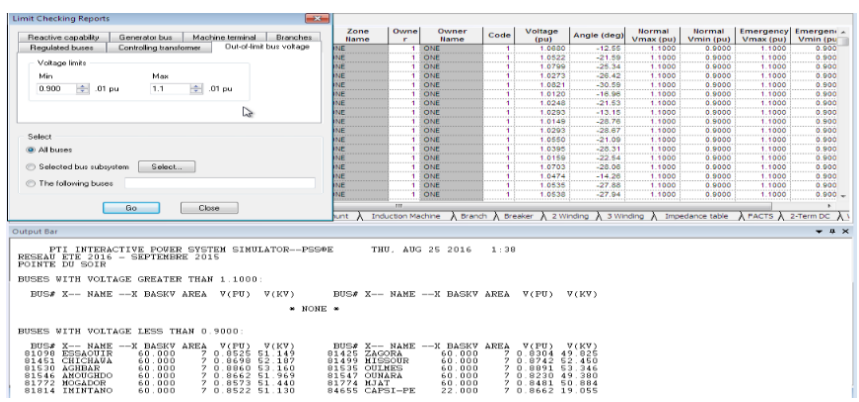

Fig13: Exceeding voltage limits

\section{Discussions}

In power flow analysis, PSS / E study the calculation of the load flow in an electrical system by balancing supply and demand. In this work, the analysis examines the stability, overloads of MV/HV lines and the exceeding of voltage limits in the Moroccan network by static examination in order to study the impact of renewable energies and the integration, in particular of wind farms and CSP power plants, in the Moroccan electricity network. The figure above represents an overview of the simulations performed.

Table 4: Summary of simulations

\begin{tabular}{cllll}
\hline & $\begin{array}{l}\text { Load } \\
\text { Flow(Stability) } \\
\text { analysis }\end{array}$ & $\begin{array}{l}\text { Border } \\
\text { trade }\end{array}$ & $\begin{array}{l}\text { Overloads } \\
\text { Analysis of } \\
\text { HV \& } \\
\text { HVB lines }\end{array}$ & $\begin{array}{l}\text { Exceeding } \\
\text { voltage } \\
\text { limits }\end{array}$ \\
\hline $\begin{array}{c}\text { Scenario } \\
\text { I }\end{array}$ & $\begin{array}{l}\text { The System } \\
\text { converges } \\
\text { without } \\
\text { problem }\end{array}$ & Positive & YES & $\begin{array}{l}\text { Yes, but } \\
\text { it's } \\
\text { tolerable }\end{array}$ \\
\hline $\begin{array}{c}\text { Scenario } \\
\text { II }\end{array}$ & $\begin{array}{l}\text { The System } \\
\text { converges } \\
\text { without } \\
\text { problem }\end{array}$ & Negative & YES & $\begin{array}{l}\text { Yes, but } \\
\text { it's } \\
\text { tolerable }\end{array}$ \\
\hline
\end{tabular}

From a point of view focused on stability and convergence, the Moroccan electricity system converges without constraints, which is justified by the investments and projects of reinforcement of $\mathrm{HV} / \mathrm{HVB}$ lines and the commissioning of several substations launched in parallel with the achievements of renewable energy projects.

As for power flows, and according to the first scenario established (maximum consumption in 2020 and maximum renewable energy production) we deduce that the objectives of the national energy strategy are achieved, namely energy independence, the integration of an energy mix with a significant share of green energy and the opening up of European energy markets. However, in the second scenario (maximum consumption in 2020 and minimum renewable 
energy production) we notice an imbalance between supply and demand which requires urgent intervention to adjust the frequency. This action calls for primary, secondary and tertiary reserves, hence the need to provide means of production that are fast, flexible and economical. These characteristics are now available in the Moroccan network with an exciting project, 'Water Transfer Station by Pumping' and another in progress Pumped Water Transfer Station (STEP) Abdelmoumen with a total capacity of both projects of $790 \mathrm{Mw}$ in Turbine mode.

Concerning the exceeding of the voltage limits, we note that in both scenarios, voltage drops are present but only in the $60 \mathrm{Kv}$ buses. These stresses can be adjusted with the installation of the steps.

For the overloads of $\mathrm{MV} / \mathrm{HV}$ lines, we notice a very low percentage of about $0.643 \%$ of the overloaded lines, this result remains very positive for a country that is in the process of inserting more than $42 \%$ of the installed power based on renewable energy.

\section{CONCLUSION}

From our study, we deduce that Morocco has been able to control on a large scale the constraints likely to weaken the national network; it has been able to make considerable steps to support the national strategy of renewable energy through several achievements. It has also been able to gain in terms of expertise, engineering and human resources. The work continues through a set of ambitious projects aimed at reducing $\mathrm{CO} 2$ emissions and ensuring green, clean and sustainable energy with the aim of achieving $52 \%$ of the installed capacity based on renewable energy.

In addition, the countries currently considering the launch and implementation of renewable energy projects need to improve :

- $\quad$ Mastering medium and long-term energy forecasts

- Supporting investments in renewable energy power plants with transmission and distribution network reinforcement projects, taking into account solutions (the construction of superconducting or HVDC lines) that reduce losses and fluctuations in voltage/reactive power.

- The power to control the additional costs related to the intermittency and variability (primary, secondary and tertiary reserves) of green energy by adopting a flexible production plan with dynamic STEPS, combined cycle power plants or gas turbines.

- To be able to involve wind and solar farms in voltage and frequency regulation.

\section{REFERENCES}

[1] IEA, 2015. Co2 emissions from fuel combustion highlight. Technical report, International Energy Agency, Paris.

[2] UmitBuluta, GonulMuratoglub "Renewable energy in
Turkey: Great potential, low but increasing utilization, and an empirical analysis on renewable energy-growth nexus"

[3] Bruce N.Stram Key challenges to expanding renewable energy

[4] T. Kousksou a, A. Allouhib, M. Belattarb, A. Jamilb, T. El Rhafikic, A. Arid C , Y. Zeraouli aRenewable energy potential and national policy directions for sustainable development in Morocco

[5] Haut-Commissariat au Plan (HCP). L'économie nationale en 2012 et 2013. In Centre National de Documentation. Haut-Commissariat au Plan, <http://www.hcp.ma/L-economie-nationale-en-2012-et2013_a1029.html>; 2009.

[6] A Bennani, J Buret, F Senhaji. Communication Nationale Initiale à la Convention Cadre des Nations Unies sur les Changements Climatiques; Ministère de l'Aménagement du Territoire de l'Urbanisme de l'Habitat et de l'Environnement: Rabat, Morocco; 2001. p. 1-101.

[7] Norton Rose Fulbright Article on Renewable Energy Morocco

http://www.nortonrosefulbright.com/knowledge/pub lications/66419/renewable-energy-in-morocco

[8] Atelier Mission Maroc, Ministère de l'énergie, des mines, de l'eau, et de l'environnement, «Les énergies renouvelables au Maroc : stratégie et Plan d'actions », Novembre 2012

[9] H. Holttinen, « The impact of large scale wind power production on the Nordic electrical system », VTT Processes, Finland, December 2004.

[10] P. S. Georgilakis, «Technical challenges associated with the integration of wind power into power systems», Renewable and Sustainable Energy Reviews 12 (2008) 852-863.

[11] T. Ackermann,"Wind Power in Power Systems", Wiley, 2005

[12] Arrêté du 4 juillet 2003 «Prescriptions techniques de conception et de fonctionnement pour le raccordement au réseau public de transport d'une installation de production d'énergie électrique », Ministère de l'économie, des finances et de l'industrie.

[13] «FINAL REPORT of the Investigation Committee on the 28 September 2003 Blackout in Italy », UCTE, Avril 2004, www.ucte.org.

[14] http://www.mem.gov.ma/SitePages/Default.aspx\#

[15] Office National de l'Electricité et Eau potable (ONEE), Chiffres clés . Available in <http://www.one.org.ma>;2018.

[16] Haut-Commissariat au Plan (HCP). L'économie nationale en 2012 et 2013. In Centre National de Documentation. Haut-Commissariat au Plan, <http://www.hcp.ma/L-economie-nationale-en-2012-et2013_a1029.html>; 2009. 
International Journal of Engineering Research and Technology. ISSN 0974-3154, Volume 13, Number 8 (2020), pp. 2081-2089 (C) International Research Publication House. https://dx.doi.org/10.37624/IJERT/13.8.2020.2081-2089

[17] T. Kousksou: Renewable energy potential and national policy directions for sustainable development in Morocco

[18] M. Hochberg"Renewable Energy Growth in Morocco”, MEI Policy Focus 2016-26

[19] Business Opportunities Report for Morocco's Renewable Energy Sector : Commissioned by the Netherlands Enterprise Agency

[20] Noreddine Citroen: Moroccan Long Term Electricity Demand Forecasting Using Wavelet Neural Networks

[21] Amin Bennouna Energy needs for Morocco 2030, as obtained from GDP-energy and GDP-energy intensity correlationsv 